\title{
COMPARING THE ENVIRONMENTAL IMPACTS OF ETHYL BIODIESEL PRODUCTION FROM SOYBEAN OIL AND BEEF TALLOW THROUGH LCA FOR BRAZILIAN CONDITIONS
}

\author{
Rafael Alves Esteves \\ Biology Institute, \\ Universidade do Estado do Rio de Janeiro (UERJ), Brazil \\ E-mail: estevesambiental@gmail.com \\ Roberto Guimarães Pereira \\ Federal Fluminense University - UFF, Brazil \\ E-mail: temrobe@vm.uff.br \\ Submission: 07/03/2017 \\ Revision: 20/03/2017 \\ Accept: 30/04/2017
}

\section{ABSTRACT}

The present paper sought compare the environmental impacts throughout the life cycle of biodiesel production obtained from the two raw materials most used in Brazil (soybean oil and beef tallow) through the process ethyl transesterification in an alkaline medium. The reference flow adopted for the work was the generation of power supplied 1GJ from the produced biodiesel. The data used in the inventory life cycle were calculated based on similar scientific papers. The method of assessment of environmental impacts chosen was the CML 2001 modified. Altogether, it were analyzed nine categories of environmental impacts for both processes (abiotic depletion (kg Sb eq), land use (m2a), global warming ( $k g \mathrm{CO}_{2} \mathrm{eq}$ ), ozone layer depletion (kg CFC-11 eq), human toxicity (kg 1,4-DB eq), freshwater ecotoxicity ( $k g$ 1,4-DB eq), terrestrial ecotoxicity ( $k g$ 1,4-DB eq), acidification ( $k g \mathrm{SO}_{2} \mathrm{eq}$ ) and eutrophication ( $\left.\mathrm{kg} \mathrm{PO}_{4}{ }^{3-} \mathrm{eq}\right)$ ). The results of evaluation of environmental impacts show that the biodiesel production process from soybean oil presents major environmental damage in seven categories of analyzed impacts (destruction of abiotic resources, destruction of the ozone layer, human toxicity, freshwater ecotoxicity, terrestrial ecotoxicity, 
INDEPENDENT JOURNAL OF MANAGEMENT \& PRODUCTION (IJM\&P)

http://www.ijmp.jor.br

v. 8, n. 4, October - December 2017

ISSN: 2236-269X

DOI: 10.14807/ijmp.v8i4.644

acidification and eutrophication). The production process of biodiesel from tallow presents major environmental damage in two categories of impacts analyzed (land use and global warming). However, the results show that the absolute values of environmental damage caused by impacts of the production process using beef tallow are much more aggressive.

Keywords: biofuels; environmental impact assessment; sustainability.

\section{INTRODUCTION}

The energy matrix of many countries is closely linked to non-renewable energy sources like oil, natural gas and coal. Such sources, used as fuels generate energy by burning it, while simultaneously produce substances that promote environmental impacts such as global warming, eutrophication, acidification, depletion of natural resources, among others (MORAIS, 2010). For this reason, due to the impacts associated with the use of energy resources of fossil origin used in the production process, the search for renewable energy sources has become a challenge today. In this sense, the energies that come from the use of renewable and less polluting fuel such as biodiesel stands out.

Biodiesel is an alternative fuel to the common diesel oil, being derived from renewable sources as, for example, soybeans, palm, castor bean, cotton, sunflower, tallow, etc. This biofuel has physic, chemical and rheological properties similar to diesel and can be used in conventional engines (PEREIRA, 2007; DEMIRBAS, 2009). Since November 1, 2014, diesel marketed throughout Brazil contains 7\% biodiesel. This rule was established by the National Council for Energy Policy (CNPE), which increased from $5 \%$ to $7 \%$ the mandatory percentage of biodiesel blends to diesel oil. The continued increase in the percentage of biodiesel added to diesel shows the success of the National Program for the Production and Use of Biodiesel (PNPB) and the experience accumulated by Brazil in the production and large-scale use of biofuels (ESTEVES; PEREIRA, 2016).

According to Viana (2008), the biggest advantage of using biodiesel is that it can be used directly in diesel engines, producing a less dirty burning when compared to regular diesel oil burning. The combustion of biodiesel in diesel engines generates a reduction in the emission of pollutant gases: sulfur oxides; 
INDEPENDENT JOURNAL OF MANAGEMENT \& PRODUCTION (IJM\&P)

http://www.ijmp.jor.br

v. 8, n. 4, October - December 2017

ISSN: 2236-269X

DOI: 10.14807/ijmp.v8i4.644

hydrocarbons; carbon dioxide and particulate matter. Furthermore, studies have shown that biodiesel is an excellent lubricant, which can increase engine life.

Thus, the study of the life cycle of biodiesel obtained from soybean oil and beef tallow, the main raw materials in the production of biodiesel in Brazil currently, has showed relevant to the extent that the search for new technologies and increased productivity is necessary in order to minimize the negative impacts caused along the biofuel production process. Studies like this one is important to seek greater environmental and economic efficiency in social niche to which the process is inserted.

Once the life cycle assessment of biodiesel considers flows of inputs and outputs for the economy and the environment, it is possible to analyze the environmental impacts throughout the production process and determine the environmental performance for each process within the studied system. Researchers have been studied different aspects of the biodiesel productive chain using LCA (CHUA et al., 2010; HANSEN et al., 2014; MANIK et al., 2013; SANDER; MURTHY, 2010; SPINELLI et al., 2013; QUEIRÓS et al., 2015; DUFOUR; IRIBARREN, 2012).

In this context, the paper presents a comparative LCA study for biodiesel production process obtained from soybean oil and beef tallow via ethylic route. This study sought to compare the input and output flows of matter and energy for each stage of the production process of the biodiesel in order to identify those most impactful and relevant in environmental terms.

\section{RESEARCH METHODOLOGY}

The methodology was developed in accordance with the ISO14040 (2009) for Life Cycle Assessment - Principles and Framework. In this standard are described the principles and the structure that an LCA study should contain and which should be adopted to a systematic approach from procurement of raw materials to final disposal, providing transparency of the study topics such as scope, the assumptions considered, to data quality and results.

The methodological framework consisted of four steps (goal and scope definition, inventory analysis, impact assessment and life cycle interpretation), as explained below. 


\subsection{First step: goal and scope defenition}

The objective of this LCA study is to identify the environmental impacts caused during the production process of biodiesel from two different raw materials: soybean oil and beef tallow. It was considered the process of transesterification via ethyl route with the use of basic catalyst for both processes in the LCA modelling.

Due to differences in physical and chemical characteristics of biodiesel from different raw materials, it is calculated the functional unit according to the calorific value of the oils. The calorific value determines the amount of energy available in the fuel and is released into the combustion chamber through a chemical reaction. In this sense, it is defined as a functional unit of this study the amount of resources required for producing $1 \mathrm{GJ}$ of energy provided by the biodiesel produced by both raw materials considered in this study.

Based on the work done by Boccardo (2004) and Cardenas (2011), the following values for calorific value of soybean oil and beef tallow were established: soybean biodiesel, $39.4 \mathrm{MJ} / \mathrm{kg}$; beef tallow biodiesel, $39.9 \mathrm{MJ} / \mathrm{kg}$. In this sense, the reference flow adopted for this study will be the amount of the biodiesel produced required to generate the total power equivalent to $1 \mathrm{GJ}$, being $25.380 \mathrm{~kg}$ in the case of soybean biodiesel and $25.062 \mathrm{~kg}$ in the case of beef tallow biodiesel.

\subsection{Second step: inventory analysis (Life Cycle Inventory - LCl)}

All data used in this study were obtained from secondary sources, with reference to other works performed by researchers who work in this line of research. The literature review consisted of consulting articles published in indexed scientific journals and theses of authors that addressed LCA studies for biofuels produced with the specificities of the national reality, whose results were applied in the construction of life cycle inventories of the raw materials used in this comparative study.

No direct contact was made with specific companies. Data not available from the sources consulted were complemented from the Ecoinvent - version 3 database, manipulated through the use of Simapro - version 8 software. All the data obtained for the accomplishment of this study of LCA are duly cited in the bibliographical references, being able to be easily searched and accessed. 
DOI: 10.14807/ijmp.v8i4.644

\subsection{Third step: impact assessment}

Step of definition of environmental impact categories. In the present study, the method of environmental impact analysis used was CML2001 v.3.01 (Non-baseline). The categories of environmental impacts studied in this study are defined by the method used and, among all the categories of impact that the method provides, the ones chosen for this study are: global warming $\left(\mathrm{kg} \mathrm{CO}_{2 \mathrm{eq}}\right)$, ozone layer depletion $(\mathrm{kg}$

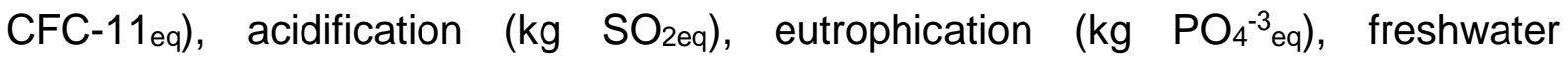
ecotoxicity ( $\mathrm{kg} 11-\mathrm{DB}$ eq), terrestrial ecotoxicity ( $\left.\mathrm{kg} 1,4 \mathrm{DB}_{\mathrm{eq}}\right)$, human toxicity $(\mathrm{kg} 1,4-$ $\left.\mathrm{DB}_{\mathrm{eq}}\right)$, destruction of abiotic resources $(\mathrm{kg} \mathrm{Sbeq})$ and land use $\left(\mathrm{m}^{2} \mathrm{a}\right)$.

\subsection{Fourth step: life cycle interpretation}

At this step, the data obtained during the study are analyzed and used in the formulation of conclusions and recommendations for the improvement of the system studied. This information can be used to analyze and select processes, inputs and equipment, and thus guide important decisions for cost reduction and technological, energy and environmental improvement.

\section{RESULTS}

\subsection{System boudaries}

This study adopted the "Cradle to Gate" LCA approach. It included as boundary, from the soybean planting phase to the production phase of the refined biodiesel, in the case of using soybean oil as a raw material, and from livestock rearing phase to production of refined biodiesel, in the case of the use of beef tallow as raw material. The process flows are showed in the Figure 1 (soybean oil) and Figure 2 (beef tallow). 


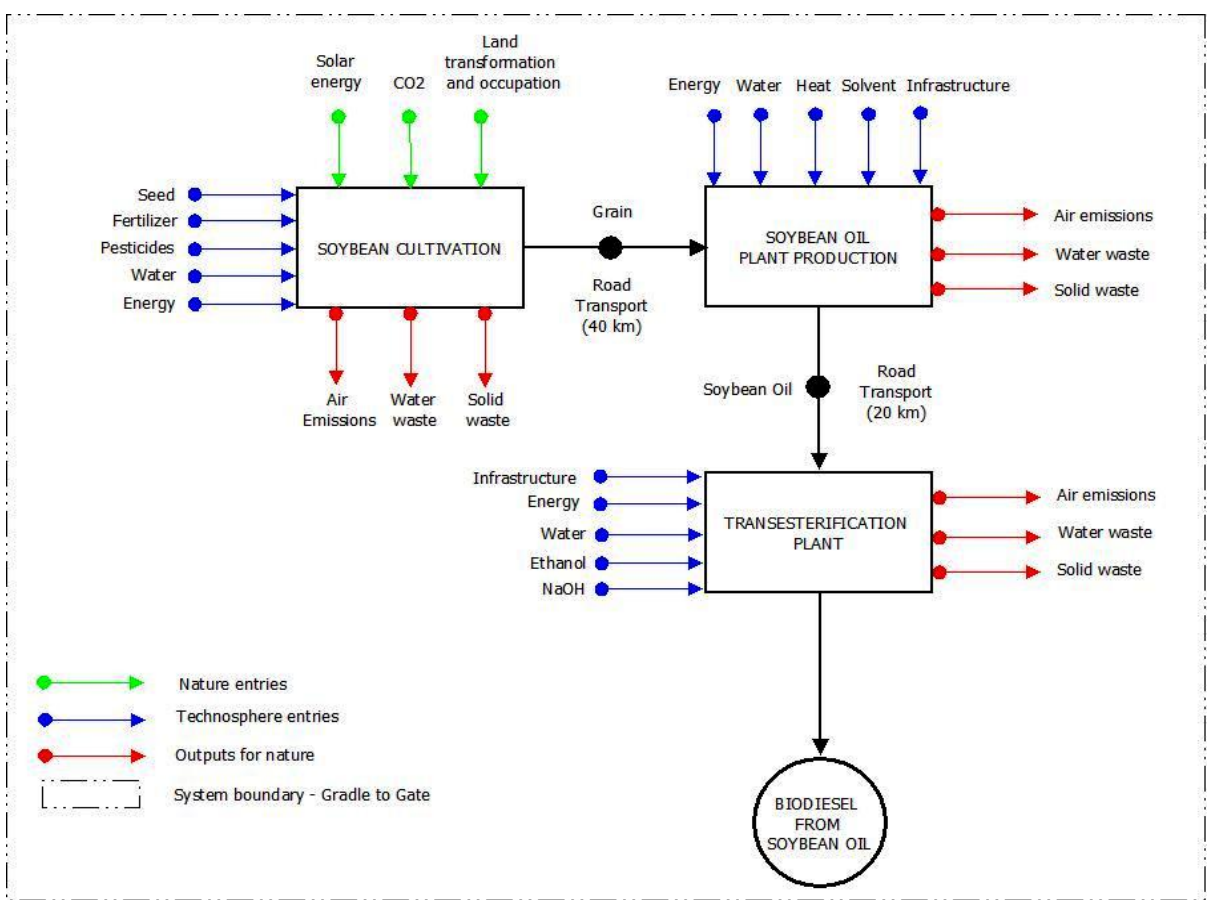

Figure 1: Process flow of biodiesel production from soybean oil.

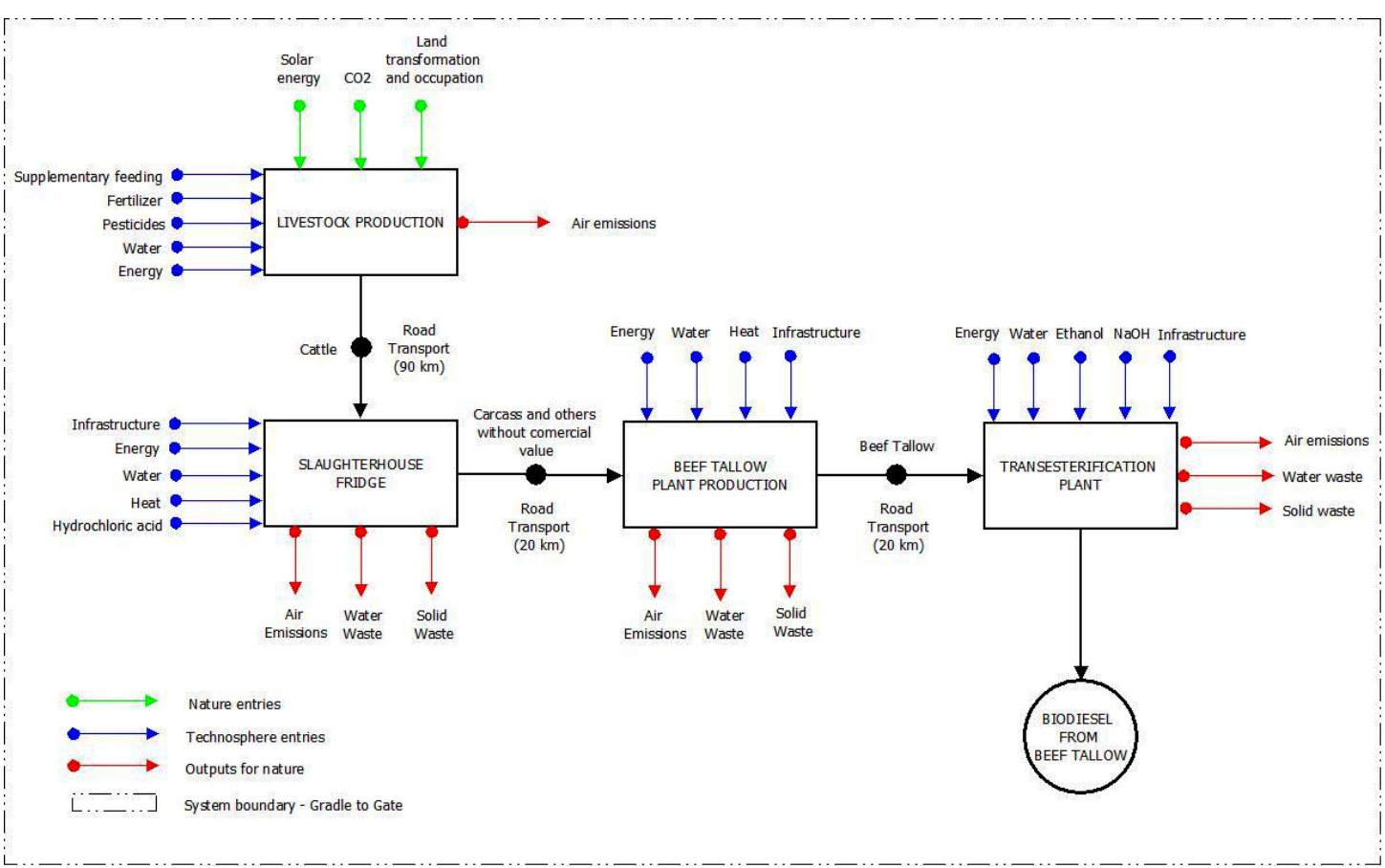

Figure 2. Process flow of biodiesel production from beef tallow.

The results of this study are pertinent to the production process of conventional biodiesel for the Brazilian conditions, produced in the Center-West region, the leading region of production in the national market, both in soy production and in livestock production. The productive processes take into account the edaphoclimatic, pedological and geographic characteristics of the Central-West region of Brazil, applying to the farming activity the extensive type. Therefore, the 
results obtained with this study should not be assumed to intensive type of production, because different data inputs and outputs are required.

\subsection{Systems allocation}

The chosen allocation parameter for soybean oil in this study was the price in the market, based on the work done by Cavallet (2008) as the relationship between the allocation factors for co-products shown in Table 1.

Table 1: Allocation factors for co-products.

\begin{tabular}{cccc}
\hline \multirow{2}{*}{ PRODUCT } & MASS FRACTION & $\begin{array}{c}\text { ENERGY FRACTION } \\
(\mathbf{\%})\end{array}$ & $\begin{array}{c}\text { PRICE FRACTION } \\
(\mathbf{\%})\end{array}$ \\
\hline Soybean meal & 81.3 & 63.0 & $\mathbf{6 0 . 7}$ \\
Soybean oil & 18.0 & 35.6 & $\mathbf{3 7 . 8}$ \\
Soy lecitin & 0.7 & 1.4 & $\mathbf{1 . 5}$ \\
\hline \multicolumn{4}{r}{}
\end{tabular}

The rationale for the choice is that when a co-product no longer has market value it becomes a waste and therefore, no material resource, energy or emissions should be allocated to him, getting all the resources used allocated to the main product. That is because it makes no sense to consider using resources to produce waste.

In the case of beef tallow allocation, according Esteves and Pereira (2016), there is not the animal slaughter only to market the tallow, so it makes no sense to use the economic allocation in this case, as for the LCA study of soybean biodiesel. For this study the chosen allocation parameter was the mass, respecting the mass percentage of $28 \%$ of beef tallow input (FELICIO, 1998; BEEFPOINT, 2013). That is, for every $100 \mathrm{~kg}$ of body weight of the slaughtered animal, this will result in the generation of $28 \mathrm{~kg}$ of beef tallow.

\subsection{Analysis inventory (Life Cycle Inventory - LCl)}

The life cycle inventory applied to soybean biodiesel is divided by basic subsystems as shown in Figure 1: soya bean crops, soybean oil production and production of soybean biodiesel through the transesterification process.

All data contained in the inventory were obtained through calculations performed for the entire reference flow for the present study, mentioned above (25.380kg of biodiesel produced, which corresponds to $1 \mathrm{GJ}$ of generated power). As 
INDEPENDENT JOURNAL OF MANAGEMENT \& PRODUCTION (IJM\&P)

http://www.ijmp.jor.br

v. 8, n. 4, October - December 2017

ISSN: 2236-269X

DOI: 10.14807/ijmp.v8i4.644

is industry knowledge that the biodiesel yield in the end of the transesterification process is not $100 \%$, a data survey in the literature on income found by other researchers in studies with soy via ethyl route in alkaline medium was carried out. However, conducting the research there was great discrepancy in the volume of work done on the subject when compared from the aspect of alcoholic route adopted for the production of biodiesel. There are many works that adopt the methyl route and just a little aims to obtain ethyl biodiesel.

For this study, the effectiveness adopted for soybean biodiesel yield at the end of the transesterification process is the same used in the work developed by the Brazilian Center of Strategic Affairs of the Presidency (NAE), conducted in 2005, which is $94.3 \%$.

According to the statement of Costa Neto et al. (2000), it is used in the biodiesel industry the molar ratio of vegetable oil to short chain alcohol of 1: 6 , and caustic soda used as a catalyst in the proportion of $0.4 \%$ over the mass of vegetable oil.

Thus, to produce $25.380 \mathrm{~kg}$ soybean biodiesel, assuming yield of $94.3 \%$, it is required $26.914 \mathrm{~kg}$ soybean oil, $7.740 \mathrm{~kg}$ of ethyl alcohol and $0.097 \mathrm{~kg}$ of caustic soda catalyst. To obtain the amount of $23.933 \mathrm{~kg}$ soybean oil is necessary the total of $91.507 \mathrm{~kg}$ of soybeans.

The values for transport were estimated based on average distances found in the actual production of biodiesel plants in Brazil. On average, the distance found for the transport between the place of the grain crop to the plant where the soybean oil extraction is performed is $40 \mathrm{~km}$ by trucks, whereas, for soybean oil carry produced in the extraction plant oil to the biodiesel production plant (plant which is made transesterification), the average distance of $20 \mathrm{~km}$ was found also done by trucks, since the rail network does not meet the major soybean producing areas in the country.

The soybean cultivation subsystem involves all activities related to the tillage process, sowing, fertilizer application, corrective soil, pesticides and grain harvesting process (Table 2). 
INDEPENDENT JOURNAL OF MANAGEMENT \& PRODUCTION (IJM\&P)

http://www.ijmp.jor.br

v. 8, n. 4, October - December 2017

ISSN: 2236-269X

DOI: 10.14807/ijmp.v8i4.644

Table 2: Soybean grain production (soybean cultivation) life cycle inventory.

\begin{tabular}{|c|c|c|c|}
\hline Name & Total & Unity & Reference \\
\hline \multicolumn{4}{|l|}{ Product of Reference } \\
\hline Soybean Grain & 1 & $\mathrm{Kg}$ & \\
\hline \multicolumn{4}{|l|}{ Nature Entries } \\
\hline Carbon dioxide, in air & $1,25 E+01$ & $\mathrm{Kg}$ & Rocha, 2011 \\
\hline Nitrogen & 2,14E-02 & $\mathrm{Kg}$ & Rocha, 2011 \\
\hline Energy, from biomass & $2,04 \mathrm{E}+01$ & $\mathrm{MJ}$ & Rocha, 2011 \\
\hline Transformation, from tropical rain forest & 7,76E-02 & $\mathrm{m} 2$ & Rocha, 2011 \\
\hline Transformation, from agriculture & $3,11 \mathrm{E}+00$ & $\mathrm{~m} 2$ & Rocha, 2011 \\
\hline Transformation, to arable & $3,31 \mathrm{E}+00$ & $\mathrm{~m} 2$ & Rocha, 2011 \\
\hline Occupation, forest & $1,26 \mathrm{E}+00$ & $\mathrm{~m} 2 \mathrm{a}$ & Rocha, 2011 \\
\hline Occupation, arable, non-irrigated & $1,66 \mathrm{E}+00$ & $\mathrm{~m} 2 \mathrm{a}$ & Rocha, 2011 \\
\hline Occupation, forest, natural & 3,38E-02 & $\mathrm{m} 2 \mathrm{a}$ & Cunha, 2008 \\
\hline Arable land use, soy bean, Brazil & $3,02 \mathrm{E}-01$ & $\mathrm{Kg}$ & Cavallet, 2008 \\
\hline Water, Surface water consumption & $8,96 \mathrm{E}+02$ & $\mathrm{Kg}$ & Cunha, 2008 \\
\hline Uranium & 1,25E-06 & $\mathrm{Kg}$ & Cunha, 2008 \\
\hline Coal, brown & 8,91E-02 & $\mathrm{Kg}$ & Cunha, 2008 \\
\hline Limestone & $1,87 \mathrm{E}+00$ & $\mathrm{Kg}$ & Ecoinvent v3 \\
\hline \multicolumn{4}{|l|}{ Technosphere Entries } \\
\hline Tillage, cultivating, chiselling & 1,95E-04 & ha & Rocha, 2011 \\
\hline Sowing & 1,33E-04 & ha & Rocha, 2011 \\
\hline Combine harvesting & 6,97E-05 & ha & Rocha, 2011 \\
\hline Potassium chloride, as $\mathrm{K} 2 \mathrm{O}$ & $1,88 \mathrm{E}-02$ & $\mathrm{~kg}$ & Rocha, 2011 \\
\hline Phosphate fertiliser, as P2O5 & 5,95E-03 & $\mathrm{kg}$ & Rocha, 2011 \\
\hline Phosphate fertiliser, as P2O5 & 3,83E-03 & $\mathrm{kg}$ & Rocha, 2011 \\
\hline Phosphate fertiliser, as P2O5 & 2,11E-03 & $\mathrm{kg}$ & Rocha, 2011 \\
\hline Phosphate rock, as $\mathrm{P} 2 \mathrm{O} 5$, beneficiated, dry & 6,61E-04 & $\mathrm{kg}$ & Rocha, 2011 \\
\hline Phosphate fertiliser, as P2O5 & $6,61 \mathrm{E}-04$ & $\mathrm{~kg}$ & Rocha, 2011 \\
\hline Fertilising, by broadcaster & 1,67E-04 & ha & Rocha, 2011 \\
\hline Pesticide, unspecified & 2,21E-03 & $\mathrm{kg}$ & Rocha, 2011 \\
\hline $\begin{array}{l}\text { Application of plant protection product, by field } \\
\text { sprayer }\end{array}$ & 1,67E-04 & ha & Rocha, 2011 \\
\hline Unknown land use, Brazil & $7,76 \mathrm{E}-02$ & $\mathrm{~m} 2$ & Cavallet, 2008 \\
\hline Glyphosate & 9,01E-01 & $\mathrm{kg}$ & Cunha, 2008 \\
\hline Dinitroaniline-compound & 2,12E-02 & $\mathrm{kg}$ & Cunha, 2008 \\
\hline 2,4-dichlorophenol & $1,00 \mathrm{E}+00$ & $\mathrm{~kg}$ & Cunha, 2008 \\
\hline Phosphoryl chloride & 1,98E-01 & $\mathrm{kg}$ & Cunha, 2008 \\
\hline Transport, freight, lorry 16-32 metric ton, EURO3 & 1,32E-01 & tkm & Ecoinvent v3 \\
\hline Diesel & $5,46 \mathrm{E}+01$ & $\mathrm{~kg}$ & Cavallet, 2008 \\
\hline Natural gas liquids & 8,06E-03 & $\mathrm{kg}$ & Cunha, 2008 \\
\hline $\begin{array}{l}\text { Electricity, high voltage }\{B R\} \mid \text { electricity production, } \\
\text { hydro, reservoir, tropical region }\end{array}$ & $7,09 \mathrm{E}+01$ & kWh & Cavallet, 2008 \\
\hline \multicolumn{4}{|l|}{ Emissions to Air } \\
\hline Dinitrogen monoxide & 7,05E-05 & $\mathrm{Kg}$ & Rocha, 2011 \\
\hline Ammonia & 2,68E-04 & $\mathrm{kg}$ & Rocha, 2011 \\
\hline Nitric oxide & 5,65E-05 & $\mathrm{kg}$ & Rocha, 2011 \\
\hline Carbon dioxide, land transformation & $1,74 \mathrm{E}+02$ & $\mathrm{~kg}$ & Cavallet, 2008 \\
\hline Methane & 3,84E-01 & $\mathrm{kg}$ & Cunha, 2008 \\
\hline Carbon monoxide, fossil & 1,15E-01 & $\mathrm{kg}$ & Cunha, 2008 \\
\hline Hydrogen sulfide & 4,75E-06 & $\mathrm{kg}$ & Cunha, 2008 \\
\hline
\end{tabular}


INDEPENDENT JOURNAL OF MANAGEMENT \& PRODUCTION (IJM\&P)

http://www.ijmp.jor.br

v. 8, n. 4, October - December 2017

ISSN: 2236-269X

DOI: 10.14807/ijmp.v8i4.644

\begin{tabular}{llll}
\hline Particulates, diesel soot & $4,82 \mathrm{E}+04$ & $\mathrm{~kg}$ & Cunha, 2008 \\
\hline Emissions to Water & & & \\
\hline Phosphorus & $1,84 \mathrm{E}-04$ & $\mathrm{~kg}$ & Rocha, 2011 \\
\hline Nitrate & $6,43 \mathrm{E}-03$ & $\mathrm{~kg}$ & Rocha, 2011 \\
\hline Ammonia & $5,78 \mathrm{E}-13$ & $\mathrm{~kg}$ & Cunha, 2008 \\
\hline Organic compounds (unspecified) & $3,00 \mathrm{E}-04$ & $\mathrm{~kg}$ & Cunha, 2008 \\
\hline COD, Chemical Oxygen Demand & $1,65 \mathrm{E}-05$ & $\mathrm{~kg}$ & Cunha, 2008 \\
\hline BOD5, Biological Oxygen Demand & $1,05 \mathrm{E}-05$ & $\mathrm{~kg}$ & Cunha, 2008 \\
\hline Metals (unspecified) & $1,95 \mathrm{E}-06$ & $\mathrm{~kg}$ & Cunha, 2008 \\
\hline Emissions to Soil & & & \\
\hline Cadmium & $7,26 \mathrm{E}-07$ & $\mathrm{~kg}$ & Rocha, 2011 \\
\hline Copper & $-1,18 \mathrm{E}-05$ & $\mathrm{~kg}$ & Rocha, 2011 \\
\hline Zinc & $-3,13 \mathrm{E}-05$ & $\mathrm{~kg}$ & Rocha, 2011 \\
\hline Lead & $2,65 \mathrm{E}-06$ & $\mathrm{~kg}$ & Rocha, 2011 \\
\hline Nickel & $-3,93 \mathrm{E}-06$ & $\mathrm{~kg}$ & Rocha, 2011 \\
\hline Chromium & $6,03 \mathrm{E}-06$ & $\mathrm{~kg}$ & Rocha, 2011 \\
\hline Pesticides, unspecified & $2,21 \mathrm{E}-01$ & $\mathrm{~kg}$ & Rocha, 2011 \\
\hline Mineral oil & $1,01 \mathrm{E}-09$ & $\mathrm{~kg}$ & Cunha, 2008 \\
\hline
\end{tabular}

Source: Prepared by the author from calculations carried out for the reference flow study based on the authors cited in the table.

The soybean oil production plant subsystem includes the activities relevant to extraction and production of soybean oil through mechanical cold pressing of the grains. The choice for this type of process is because it is widely used in most Brazilian companies and reflects the national scene for industrial segment (Table 3).

Table 3: Soybean oil plant production life cycle inventory.

\begin{tabular}{|c|c|c|c|}
\hline Name & Total & Unity & Reference \\
\hline \multicolumn{4}{|l|}{ Product of Reference } \\
\hline Soybean Oil & 1 & $\mathrm{Kg}$ & \\
\hline \multicolumn{4}{|l|}{ Nature Entries } \\
\hline Water, Surface water consumption & $2,04 \mathrm{E}+03$ & $\mathrm{~kg}$ & Cavallet, 2008 \\
\hline \multicolumn{4}{|l|}{ Technosphere Entries } \\
\hline Soybean Grain & $3,40 E+00$ & $\mathrm{~kg}$ & \\
\hline Tap water, at user & $1,73 E+00$ & $\mathrm{~kg}$ & Rocha, 2011 \\
\hline Hexane & $3,40 E+00$ & $\mathrm{~kg}$ & Cavallet, 2008 \\
\hline $\begin{array}{l}\text { Phosphoric acid, industrial grade, without water, in } \\
85 \% \text { solution state }\end{array}$ & $2,55 \mathrm{E}-01$ & $\mathrm{~kg}$ & Cavallet, 2008 \\
\hline $\begin{array}{l}\text { Sodium hydroxide, without water, in } 50 \% \text { solution } \\
\text { state }\end{array}$ & $2,28 \mathrm{E}+00$ & $\mathrm{~kg}$ & Cavallet, 2008 \\
\hline Citric acid & 3,06E-03 & $\mathrm{kg}$ & Cavallet, 2008 \\
\hline Transport, freight, lorry 16-32 metric ton, EURO3 & 1,16E-01 & tkm & Ecoinvent v3 \\
\hline Vegetable oil refinery & $3,70 \mathrm{E}-10$ & $p$ & Ecoinvent v3 \\
\hline Clay & $1,78 \mathrm{E}+00$ & $\mathrm{~kg}$ & Cavallet, 2008 \\
\hline $\begin{array}{l}\text { Heat, district or industrial, other than natural gas } \\
\text { \{BR\} }\end{array}$ & $2,64 \mathrm{E}+00$ & $\mathrm{MJ}$ & Rocha, 2011 \\
\hline $\begin{array}{l}\text { Electricity, high voltage }\{B R\} \mid \text { electricity production, } \\
\text { hydro, reservoir, tropical region }\end{array}$ & $5,22 \mathrm{E}-01$ & $\mathrm{MJ}$ & Rocha, 2011 \\
\hline \multicolumn{4}{|l|}{ Emissions to Air } \\
\hline Hexane & $3,70 \mathrm{E}-03$ & $\mathrm{~kg}$ & Rocha, 2011 \\
\hline Water & 9,45E-05 & $\mathrm{kg}$ & Cunha, 2008 \\
\hline
\end{tabular}


INDEPENDENT JOURNAL OF MANAGEMENT \& PRODUCTION (IJM\&P)

http://www.ijmp.jor.br

v. 8, n. 4, October - December 2017

ISSN: 2236-269X

DOI: 10.14807/ijmp.v8i4.644

\begin{tabular}{llll}
\hline Ammonia & $2,46 \mathrm{E}-15$ & $\mathrm{~kg}$ & Cunha, 2008 \\
\hline Methane & $7,73 \mathrm{E}-04$ & $\mathrm{~kg}$ & Cunha, 2008 \\
\hline Carbon monoxide & $1,45 \mathrm{E}-05$ & $\mathrm{~kg}$ & Cunha, 2008 \\
Carbon dioxide & $1,23 \mathrm{E}-01$ & $\mathrm{~kg}$ & Cunha, 2008 \\
Nitrogen monoxide & $9,25 \mathrm{E}-08$ & $\mathrm{~kg}$ & Cunha, 2008 \\
Nitrogen oxides & $5,32 \mathrm{E}-05$ & $\mathrm{~kg}$ & Cunha, 2008 \\
\hline Sulfur dioxide & $1,14 \mathrm{E}-08$ & $\mathrm{~kg}$ & Cunha, 2008 \\
Sulfur oxides & $3,15 \mathrm{E}-07$ & $\mathrm{~kg}$ & Cunha, 2008 \\
\hline Particulates, diesel soot & $5,13 \mathrm{E}-08$ & $\mathrm{~kg}$ & Cunha, 2008 \\
Emissions to Water & & & \\
Water & $3,70 \mathrm{E}-04$ & $\mathrm{~kg}$ & Cunha, 2008 \\
\hline Ammonia & $4,77 \mathrm{E}-13$ & $\mathrm{~kg}$ & Cunha, 2008 \\
\hline Organic compounds (unspecified) & $1,48 \mathrm{E}-06$ & $\mathrm{~kg}$ & Cunha, 2008 \\
BOD5, Biological Oxygen Demand & $8,30 \mathrm{E}-06$ & $\mathrm{~kg}$ & Cunha, 2008 \\
COD, Chemical Oxygen Demand & $1,29 \mathrm{E}-05$ & $\mathrm{~kg}$ & Cunha, 2008 \\
\hline Metals (unspecified) & $1,55 \mathrm{E}-06$ & $\mathrm{~kg}$ & Cunha, 2008 \\
\hline
\end{tabular}

Source: Prepared by the author from calculations carried out for the reference flow study based on the authors cited in the table.

The process of the soybean biodiesel production plant subsystem includes the activities relevant to the production of biodiesel through the ethyl transesterification, under alkaline conditions. The transesterification is the technology most widely used not only in production processes in Brazil, but also in the world. The Table 4 presents the inventory data to the subsystem relating to biodiesel production of soybean (transesterification).

Table 4: Soybean biodiesel production plant life cycle inventory.

\begin{tabular}{|c|c|c|c|}
\hline Name & Total & Unity & Reference \\
\hline \multicolumn{4}{|l|}{ Product of Reference } \\
\hline Soybean Biodiesel & 1 & $\mathrm{Kg}$ & \\
\hline \multicolumn{4}{|l|}{ Nature Entries } \\
\hline Water, process, unspecified natural origin $/ \mathrm{kg}$ & $9,12 \mathrm{E}+02$ & $\mathrm{~kg}$ & Cunha, 2008 \\
\hline \multicolumn{4}{|l|}{ Technosphere Entries } \\
\hline Soybean Oil & $9,42 \mathrm{E}-01$ & $\mathrm{~kg}$ & \\
\hline Tap water, at user & 4,34E-01 & $\mathrm{kg}$ & Rocha, 2011 \\
\hline $\begin{array}{l}\text { Ethanol, without water, in } 95 \% \text { solution state, from } \\
\text { fermentation }\{B R\}\end{array}$ & $3,04 \mathrm{E}-01$ & $\mathrm{~kg}$ & Ecoinvent v3 \\
\hline $\begin{array}{l}\text { Sodium hydroxide, without water, in } 50 \% \text { solution } \\
\text { state }\end{array}$ & $3,82 \mathrm{E}-03$ & $\mathrm{~kg}$ & Ecoinvent v3 \\
\hline Vegetable oil esterification facility & $8,60 \mathrm{E}-10$ & $\mathrm{p}$ & Ecoinvent v3 \\
\hline Transport, freight, lorry $16-32$ metric ton, EURO3 & 1,50E-01 & $\mathrm{tkm}$ & Ecoinvent v3 \\
\hline $\begin{array}{l}\text { Heat, district or industrial, other than natural gas } \\
\{B R\}\end{array}$ & $7,35 \mathrm{E}-02$ & MJ & Rocha, 2011 \\
\hline $\begin{array}{l}\text { Electricity, high voltage }\{B R\} \mid \text { electricity production, } \\
\text { hydro, reservoir, tropical region }\end{array}$ & $2,70 \mathrm{E}-01$ & MJ & Rocha, 2011 \\
\hline \multicolumn{4}{|l|}{ Emissions to Air } \\
\hline Water & $1,68 \mathrm{E}+00$ & $\mathrm{~kg}$ & Cunha, 2008 \\
\hline Methane & 7,81E-03 & $\mathrm{kg}$ & Cunha, 2008 \\
\hline Carbon monoxide & 1,29E-03 & $\mathrm{kg}$ & Cunha, 2008 \\
\hline Carbon dioxide & 2,00E-01 & $\mathrm{kg}$ & Cunha, 2008 \\
\hline Hydrogen sulfide & 2,13E-09 & $\mathrm{kg}$ & Cunha, 2008 \\
\hline
\end{tabular}


INDEPENDENT JOURNAL OF MANAGEMENT \& PRODUCTION (IJM\&P)

http://www.ijmp.jor.br

v. 8, n. 4, October - December 2017

ISSN: 2236-269X

DOI: 10.14807/ijmp.v8i4.644

\begin{tabular}{|c|c|c|c|}
\hline Metals, unspecified & 4,71E-08 & $\mathrm{kg}$ & Cunha, 2008 \\
\hline Nitrogen monoxide & 7,99E-05 & $\mathrm{kg}$ & Cunha, 2008 \\
\hline Nitrogen oxides & $4,68 \mathrm{E}-03$ & $\mathrm{~kg}$ & Cunha, 2008 \\
\hline Sulfur dioxide & $5,12 \mathrm{E}-04$ & $\mathrm{~kg}$ & Cunha, 2008 \\
\hline Sulfur oxides & $9,89 E-04$ & $\mathrm{~kg}$ & Cunha, 2008 \\
\hline \multicolumn{4}{|l|}{ Emissions to Water } \\
\hline Waste water/m3 & 8,88E-03 & I & Cunha, 2008 \\
\hline Ammonia & $6,00 \mathrm{E}-11$ & $\mathrm{~kg}$ & Cunha, 2008 \\
\hline Organic compounds (unspecified) & 9,68E-06 & $\mathrm{kg}$ & Cunha, 2008 \\
\hline BOD5, Biological Oxygen Demand & 4,46E-05 & $\mathrm{kg}$ & Cunha, 2008 \\
\hline COD, Chemical Oxygen Demand & 8,26E-05 & $\mathrm{kg}$ & Cunha, 2008 \\
\hline Metals (unspecified) & 7,97E-06 & $\mathrm{kg}$ & Cunha, 2008 \\
\hline \multicolumn{4}{|l|}{ Emissions to Soil } \\
\hline Mineral oil & $4,29 \mathrm{E}-04$ & $\mathrm{~kg}$ & Cunha, 2009 \\
\hline
\end{tabular}

The life cycle inventory applied to the production of beef tallow biodiesel is divided by basic subsystems as shown in Figure 2: livestock production, slaughter and fridge process, tallow production and biodiesel production through the transesterification process.

All data contained in the inventory were obtained through calculations performed for the entire reference flow for the present study $(25.062 \mathrm{~kg}$ of biodiesel produced, corresponding to $1 \mathrm{GJ}$ of energy generated).

For this study, the efficiency adopted for beef tallow biodiesel yield the end of the transesterification process is as seen in the work of Lopes (2006), which is $80 \%$. According to the experiments Lopes (2006), proved reasonable to use the molar ratio of 1:6 in ratio of animal fat to ethanol, and caustic soda as catalyst in the proportion of $1.5 \%$ compared to of fat mass.

Thus, to produce $25.062 \mathrm{~kg}$ of beef tallow biodiesel, assuming yield of $80 \%$, are needed $31,327 \mathrm{~kg}$ of beef tallow, $9.724 \mathrm{~kg}$ of ethyl alcohol and $0.360 \mathrm{~kg}$ of caustic soda catalyst. To obtain the amount of $31,327 \mathrm{~kg}$ of beef tallow is required the total of 7.51@ cattle entering the slaughter (equivalent to $\sim 112,5 \mathrm{~kg}$ ).

The transport of products from the elementary stages of the production chain of the beef tallow biodiesel were estimated based on average distances found in the reality of production chain involving the relationship between the farms, slaughterhouses and biodiesel plants in Brazil. On average, the distance found for transportation of cattle from the production site to the refrigerator (which is carried out the slaughter and separation of the commercial meat, bones, drainage and collection of blood, leather and fat from slaughtered animals) is $90 \mathrm{~km}$ done by truck. 
INDEPENDENT JOURNAL OF MANAGEMENT \& PRODUCTION (IJM\&P)

http://www.ijmp.jor.br

v. 8, n. 4, October - December 2017

ISSN: 2236-269X

DOI: 10.14807/ijmp.v8i4.644

It was considered the distance of $20 \mathrm{~km}$ between the refrigerator and the production plant of beef tallow to serve as feedstock for biodiesel production in the transesterification plant. And finally transport, was considered the distance of over $20 \mathrm{~km}$ from the production of beef tallow to biodiesel production plant (transesterification).

Cattle production subsystem involves all activities related to the process of occupation and transformation of the land for grazing, application of pesticides, the use of fuels for carrying out production operations, water consumption and energy production of the mineral salt, transportation of inputs and animals and all infrastructure needs in treasury. The Table 5 presents the inventory data to the subsystem concerning the production of livestock.

Table 5: Livestock production life cycle inventory.

\begin{tabular}{|c|c|c|c|}
\hline Name & Total & Unity & Reference \\
\hline \multicolumn{4}{|l|}{ Product of Reference } \\
\hline Cattle & 1 & $@$ & \\
\hline \multicolumn{4}{|l|}{ Nature Entries } \\
\hline Water, unspecified natural origin, BR & 1,31E-01 & m3 & Willers, 2014 \\
\hline Wood, unspecified, standing/m3 & 4,87E-01 & m3 & Willers, 2014 \\
\hline Occupation, pasture and meadow & $2,70 \mathrm{E}-01$ & ha a & Willers, 2014 \\
\hline \multicolumn{4}{|l|}{ Technosphere Entries } \\
\hline Housing system, cattle, loose, per animal unit & 4,20E-05 & $\mathrm{p}$ & Willers, 2014 \\
\hline Salt tailing from potash mine & $2,25 \mathrm{E}+00$ & $\mathrm{~kg}$ & Ecoinvent v3 \\
\hline Wire drawing, steel & 1,28E-01 & $\mathrm{kg}$ & Ecoinvent v3 \\
\hline Dichloropropene & $1,25 \mathrm{E}-02$ & $\mathrm{~kg}$ & Ecoinvent v3 \\
\hline $\begin{array}{l}\text { Application of plant protection product, by field } \\
\text { sprayer }\end{array}$ & $6,25 E-04$ & ha & Ecoinvent v3 \\
\hline 2,4-dichlorophenol & 1,06E-02 & $\mathrm{kg}$ & Ecoinvent v3 \\
\hline $\begin{array}{l}\text { Operation, housing system, cattle, loose, per animal } \\
\text { unit }\end{array}$ & 3,00E-05 & $\mathrm{p}$ & Ecoinvent v3 \\
\hline Transport, freight, lorry >32 metric ton, EURO3 & $4,50 E-01$ & $\mathrm{tkm}$ & Ecoinvent v3 \\
\hline $\begin{array}{l}\text { Unknown land use }\{B R\} \mid \text { unkown land use, on } \\
\text { arable land recently transformed from primary forest }\end{array}$ & 3,10E-02 & $\mathrm{m} 2$ & Ecoinvent v3 \\
\hline $\begin{array}{l}\text { Electricity, medium voltage }\{B R\} \mid \text { electricity voltage } \\
\text { transformation from high to medium voltage }\end{array}$ & $9,38 \mathrm{E}+00$ & $\mathrm{MJ}$ & Willers, 2014 \\
\hline Diesel & $4,25 E-01$ & $\mathrm{~kg}$ & Willers, 2014 \\
\hline \multicolumn{4}{|l|}{ Emissions to Air } \\
\hline Methane & $10,73 E+00$ & $\mathrm{~kg}$ & Willers, 2014 \\
\hline Dinitrogen monoxide & $9,70 \mathrm{E}-02$ & $\mathrm{~kg}$ & Willers, 2014 \\
\hline Nitrogen & $9,24 \mathrm{E}-01$ & $\mathrm{~kg}$ & Willers, 2014 \\
\hline
\end{tabular}

Source: Prepared by the author from calculations carried out for the reference flow study based on the authors cited in the table.

The slaughterhouse and fridge process subsystem includes the activities related to the receipt of animals in pens reception, the animals rest in water diet, animal cleaning, channeling of animal the slaughter room, Application stunning 
INDEPENDENT JOURNAL OF MANAGEMENT \& PRODUCTION (IJM\&P)

http://www.ijmp.jor.br

v. 8, n. 4, October - December 2017

ISSN: 2236-269X

DOI: 10.14807/ijmp.v8i4.644

technique (widely used air gun) slaughter of animals and separation of the parts of the slaughtered animal (Table 6).

Table 6: Slaughterhouse and fridge process life cycle inventory.

\begin{tabular}{|c|c|c|c|}
\hline Name & Total & Unity & Reference \\
\hline \multicolumn{4}{|l|}{ Product of Reference } \\
\hline Carcass & 1 & $\mathrm{Kg}$ & \\
\hline \multicolumn{4}{|l|}{ Recursos da Natureza } \\
\hline Water, unspecified natural origin, BR & $2,78 \mathrm{E}+00$ & m3 & Cunha, 2008 \\
\hline \multicolumn{4}{|l|}{ Technosphere Entries } \\
\hline Livestock Production & $1,00 \mathrm{E}+00$ & $\mathrm{~kg}$ & \\
\hline $\begin{array}{l}\text { Hydrochloric acid, without water, in } 30 \% \text { solution } \\
\text { state }\end{array}$ & 1,36E-03 & $\mathrm{kg}$ & Cunha, 2008 \\
\hline Diesel & $9,69 \mathrm{E}-04$ & $\mathrm{~kg}$ & Cunha, 2008 \\
\hline Steam, in chemical industry & $1,23 E+02$ & $\mathrm{~kg}$ & Ecoinvent v3 \\
\hline Transport, freight, lorry 16-32 metric ton, EURO3 & 2,12E-01 & tkm & Ecoinvent v3 \\
\hline $\begin{array}{l}\text { Heat, district or industrial, other than natural gas } \\
\text { \{BR\}| heat and power co-generation, diesel, } 200 \mathrm{~kW} \\
\text { electrical, SCR-NOx reduction }\end{array}$ & $2,52 \mathrm{E}-02$ & $\mathrm{MJ}$ & Cunha, 2008 \\
\hline $\begin{array}{l}\text { Electricity, high voltage }\{B R\} \mid \text { electricity production, } \\
\text { hydro, reservoir, tropical region }\end{array}$ & $5,12 \mathrm{E}-01$ & $\mathrm{MJ}$ & Cunha, 2008 \\
\hline \multicolumn{4}{|l|}{ Emissions to Air } \\
\hline Carbon dioxide & 3,05E-03 & $\mathrm{kg}$ & Cunha, 2008 \\
\hline Water & $1,84 \mathrm{E}-01$ & $\mathrm{~kg}$ & Cunha, 2008 \\
\hline Methane & $4,35 \mathrm{E}-04$ & $\mathrm{~kg}$ & Cunha, 2008 \\
\hline \multicolumn{4}{|l|}{ Emissions to Water } \\
\hline Waste water/m3 & 1,76E-05 & m3 & Cunha, 2008 \\
\hline BOD5, Biological Oxygen Demand & 5,15E-03 & $\mathrm{kg}$ & Cunha, 2008 \\
\hline COD, Chemical Oxygen Demand & 1,03E-02 & $\mathrm{kg}$ & Cunha, 2008 \\
\hline Organic compounds (unspecified) & 9,76E-04 & $\mathrm{kg}$ & Cunha, 2008 \\
\hline
\end{tabular}

Source: Prepared by the author from calculations carried out for the reference flow study based on the authors cited in the table.

The beef tallow production subsystem includes the steps inherent to the tallow production process from the process waste from the refrigerator, the main components bones, carcasses, fats and animal shavings cut during separation of the parts. The Table 7 presents the inventory data to the subsystem relating to the production process of beef tallow.

Table 7: Beef tallow production life cycle inventory.

\begin{tabular}{llll}
\hline Name & Total & Unity & Reference \\
\hline Product of Reference & 1 & $\mathrm{Kg}$ & \\
$\begin{array}{l}\text { Beef Tallow } \\
\text { Nature Entries }\end{array}$ & & & \\
$\begin{array}{l}\text { Water, unspecified natural origin, BR } \\
\text { Technosphere Entries }\end{array}$ & $2,78 \mathrm{E}-01$ & $\mathrm{~kg}$ & Cunha, 2008 \\
$\begin{array}{l}\text { Carcass Production } \\
\text { Transport, freight, lorry 16-32 metric ton, EURO3 }\end{array}$ & $2,00 \mathrm{E}+00$ & $\mathrm{~kg}$ & \\
$\begin{array}{l}\text { Electricity, high voltage }\{\mathrm{BR}\} \mid \text { electricity production, } \\
\text { hydro, reservoir, tropical region }\end{array}$ & $8,00 \mathrm{E}+02$ & $\mathrm{tkm}$ & Ecoinvent $\mathrm{v3}$ \\
Natural gas liquids & $2,52 \mathrm{E}-02$ & $\mathrm{MJ}$ & Cunha, 2008 \\
\hline
\end{tabular}


INDEPENDENT JOURNAL OF MANAGEMENT \& PRODUCTION (IJM\&P)

http://www.ijmp.jor.br

v. 8, n. 4, October - December 2017

ISSN: 2236-269X

DOI: 10.14807/ijmp.v8i4.644

\begin{tabular}{lccc}
\hline Diesel & 6,01E-04 & $\mathrm{kg}$ & Cunha, 2008 \\
\hline Emissions to Air & & & \\
Water & $1,84 \mathrm{E}-01$ & $\mathrm{~kg}$ & Cunha, 2008 \\
Methane & $4,35 \mathrm{E}-04$ & $\mathrm{~kg}$ & Cunha, 2008 \\
Ammonia & $4,80 \mathrm{E}-12$ & $\mathrm{~kg}$ & Cunha, 2008 \\
Carbon monoxide & $1,22 \mathrm{E}-04$ & $\mathrm{~kg}$ & Cunha, 2008 \\
Carbon dioxide & $3,05 \mathrm{E}-03$ & $\mathrm{~kg}$ & Cunha, 2008 \\
Hydrogen sulfide & $1,87 \mathrm{E}-17$ & $\mathrm{~kg}$ & Cunha, 2008 \\
Particulates, diesel soot & $5,41 \mathrm{E}-05$ & $\mathrm{~kg}$ & Cunha, 2008 \\
Metals, unspecified & $4,34 \mathrm{E}-10$ & $\mathrm{~kg}$ & Cunha, 2008 \\
Dinitrogen monoxide & $8,83 \mathrm{E}-06$ & $\mathrm{~kg}$ & Cunha, 2008 \\
Nitrogen oxides & $4,72 \mathrm{E}-04$ & $\mathrm{~kg}$ & Cunha, 2008 \\
Sulfur dioxide & $5,45 \mathrm{E}-10$ & $\mathrm{~kg}$ & Cunha, 2008 \\
Sulfur oxides & $9,34 \mathrm{E}-05$ & $\mathrm{~kg}$ & Cunha, 2008 \\
Emissions to Water & & & \\
Waste water/m3 & $1,76 \mathrm{E}-07$ & $\mathrm{~kg}$ & Cunha, 2008 \\
Ammonia & $2,27 \mathrm{E}-14$ & $\mathrm{~kg}$ & Cunha, 2008 \\
Organic chlorine compounds (unspecified) & $9,76 \mathrm{E}-04$ & $\mathrm{~kg}$ & Cunha, 2008 \\
BOD5, Biological Oxygen Demand & $5,15 \mathrm{E}-03$ & $\mathrm{~kg}$ & Cunha, 2008 \\
COD, Chemical Oxygen Demand & $1,03 \mathrm{E}-02$ & $\mathrm{~kg}$ & Cunha, 2008 \\
Metals (unspecified) & $8,19 \mathrm{E}-08$ & $\mathrm{~kg}$ & Cunha, 2008 \\
Emissions to Soil & & & \\
Process waste & $8,56 \mathrm{E}-03$ & $\mathrm{~kg}$ & Cunha, 2008 \\
Waste, industrial & $4,24 \mathrm{E}-08$ & $\mathrm{~kg}$ & Cunha, 2008 \\
Mineral waste & $3,79 \mathrm{E}-06$ & $\mathrm{~kg}$ & Cunha, 2008 \\
\hline
\end{tabular}

Source: Prepared by the author from calculations carried out for the reference flow study based on the authors cited in the table.

The beef tallow biodiesel production subsystem includes the activities relevant to the production of biodiesel through the ethyl transesterification, under alkaline conditions. The transesterification is the technology most widely used not only in production processes in Brazil, but also in the world. The Table 8 presents the inventory data to the subsystem relating to the production process of beef tallow biodiesel through the transesterification process.

Table 8: Beef tallow biodiesel production (transesterification) life cycle inventory.

\begin{tabular}{|c|c|c|c|}
\hline Name & Total & Unity & Reference \\
\hline \multicolumn{4}{|l|}{ Product of Reference } \\
\hline Beef Tallow Biodiesel & 1 & $\mathrm{Kg}$ & \\
\hline \multicolumn{4}{|l|}{ Nature Entries } \\
\hline Water, unspecified natural origin, BR & 2,96E-01 & m3 & Cunha, 2008; Lopes, 2006 \\
\hline \multicolumn{4}{|l|}{ Technosphere Entries } \\
\hline Beef Tallow Production & $1,00 \mathrm{E}+00$ & $\mathrm{~kg}$ & \\
\hline $\begin{array}{l}\text { Ethanol, without water, in } 95 \% \text { solution state, from } \\
\text { fermentation }\{B R\}\end{array}$ & 3,04E-01 & $\mathrm{kg}$ & Ecoinvent v3 \\
\hline $\begin{array}{l}\text { Sodium hydroxide, without water, in } 50 \% \text { solution } \\
\text { state }\end{array}$ & 3,82E-03 & $\mathrm{kg}$ & Ecoinvent v3 \\
\hline Vegetable oil esterification facility & $8,60 \mathrm{E}-10$ & p & Ecoinvent v3 \\
\hline Transport, freight, lorry 16-32 metric ton, EURO3 & $1,50 \mathrm{E}-01$ & $\mathrm{tkm}$ & Ecoinvent v3 \\
\hline $\begin{array}{l}\text { Heat, district or industrial, other than natural gas } \\
\{B R\}\end{array}$ & $1,20 \mathrm{E}-01$ & $\mathrm{MJ}$ & Lopes, 2006 \\
\hline $\begin{array}{l}\text { Electricity, high voltage }\{B R\} \mid \text { electricity production, } \\
\text { hydro, reservoir, tropical region }\end{array}$ & 1,86E-01 & MJ & Lopes, 2006 \\
\hline \multicolumn{4}{|l|}{ Emissions to Air } \\
\hline Water & 2,22E-01 & $\mathrm{kg}$ & Cunha, 2008 \\
\hline Ammonia & $5,11 \mathrm{E}-12$ & $\mathrm{~kg}$ & Cunha, 2008 \\
\hline Methane & $3,56 \mathrm{E}-01$ & $\mathrm{~kg}$ & Cunha, 2008 \\
\hline Carbon monoxide & $4,75 \mathrm{E}-04$ & $\mathrm{~kg}$ & Cunha, 2008 \\
\hline Carbon dioxide & 1,66E-01 & $\mathrm{kg}$ & Cunha, 2008 \\
\hline
\end{tabular}


INDEPENDENT JOURNAL OF MANAGEMENT \& PRODUCTION (IJM\&P)

http://www.ijmp.jor.br

v. 8, n. 4, October - December 2017

ISSN: 2236-269X

DOI: 10.14807/ijmp.v8i4.644

\begin{tabular}{llll}
\hline Hydrogen sulfide & $8,31 \mathrm{E}-16$ & $\mathrm{~kg}$ & Cunha, 2008 \\
Particulates, diesel soot & $9,45 \mathrm{E}-05$ & $\mathrm{~kg}$ & Cunha, 2008 \\
Metals, unspecified & $1,86 \mathrm{E}-08$ & $\mathrm{~kg}$ & Cunha, 2008 \\
Nitrogen monoxide & $1,08 \mathrm{E}-05$ & $\mathrm{~kg}$ & Cunha, 2008 \\
Nitrogen oxides & $1,06 \mathrm{E}-03$ & $\mathrm{~kg}$ & Cunha, 2008 \\
Sulfur dioxide & $3,33 \mathrm{E}-04$ & $\mathrm{~kg}$ & Cunha, 2008 \\
Sulfur oxides & $1,11 \mathrm{E}-04$ & $\mathrm{~kg}$ & Cunha, 2008 \\
Emissions to Water & & & \\
Waste water/m3 & & $\mathrm{m} 3$ & Cunha, 2008 \\
Ammonia & $7,68 \mathrm{E}-05$ & $\mathrm{~kg}$ & Cunha, 2008 \\
Organic chlorine compounds (unspecified) & $9,88 \mathrm{E}-13$ & $\mathrm{~kg}$ & Cunha, 2008 \\
BOD5, Biological Oxygen Demand & $9,77 \mathrm{E}-04$ & $\mathrm{~kg}$ & Cunha, 2008 \\
COD, Chemical Oxygen Demand & $5,16 \mathrm{E}-03$ & $\mathrm{~kg}$ & Cunha, 2008 \\
Metals (unspecified) & $1,03 \mathrm{E}-02$ & $\mathrm{~kg}$ & Cunha, 2008 \\
Organic compounds (dissolved) & $3,21 \mathrm{E}-06$ & $\mathrm{~kg}$ & Cunha, 2008 \\
Suspended solids, unspecified & $5,16 \mathrm{E}-04$ & $\mathrm{~kg}$ & Cunha, 2008 \\
Emissions to Soil & $4,19 \mathrm{E}-03$ & & Cunha, 2008 \\
Process waste & & $\mathrm{kg}$ & Cunha, 2008 \\
Mineral waste & & $\mathrm{kg}$ & Cunha, 2008 \\
\hline Waste, organic & $9,11 \mathrm{E}-03$ & $\mathrm{~kg}$ & $1,37 \mathrm{E}-04$ \\
\hline
\end{tabular}

Source: Prepared by the author from calculations carried out for the reference flow study based on the authors cited in the table.

\subsection{Life cycle impact analysis}

The Figure 3 compares the environmental impacts generated by life cycle of soybean biodiesel with the life cycle of beef tallow biodiesel as a percentage, which distributes the weight of the environmental impacts between categories of impact.

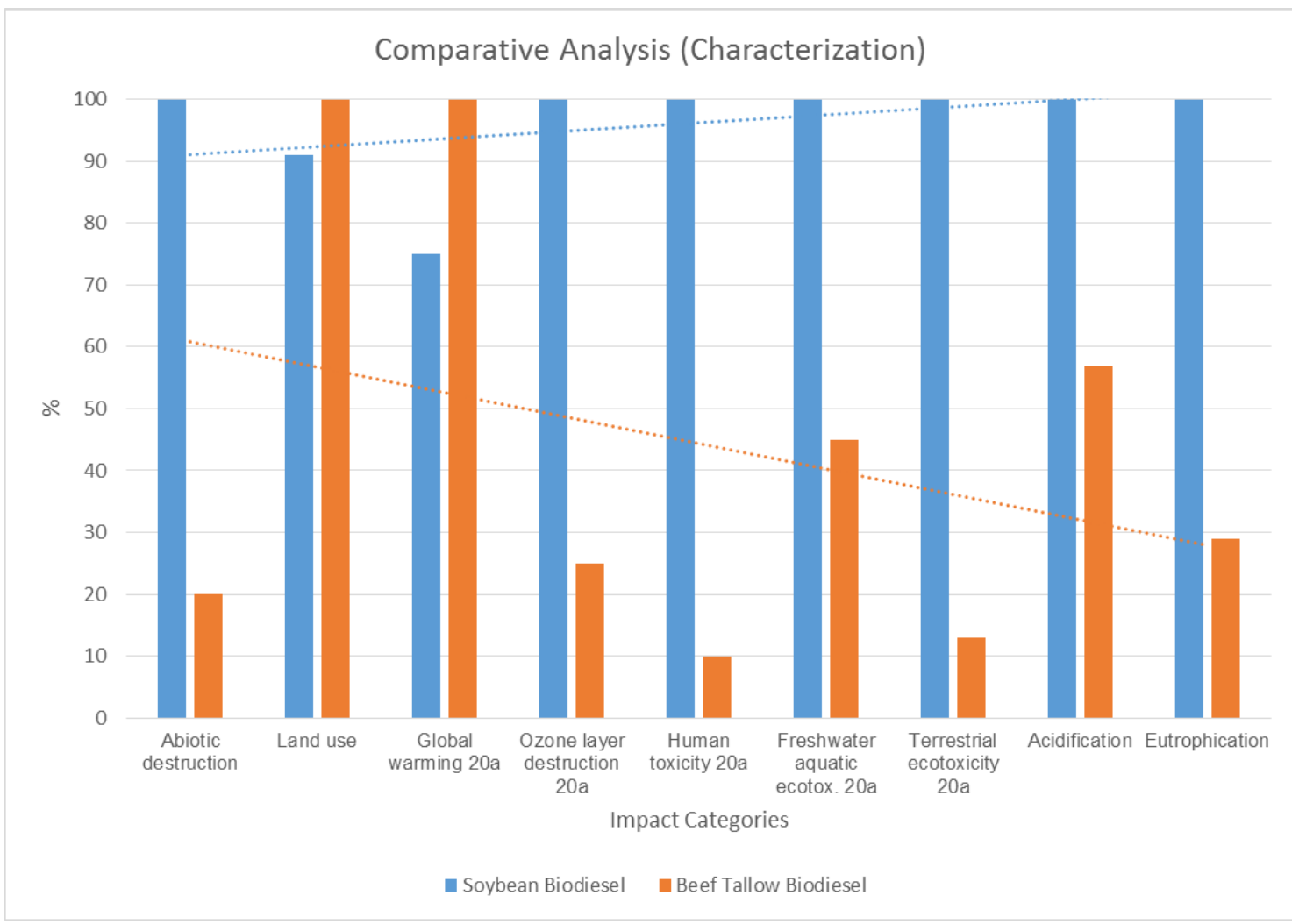

Figure 3. Comparative analysis of the impacts in percentage (characterization).

The results show that the life cycle of soybean biodiesel has environmental impacts in most impact categories analyzed: destruction of abiotic resources, 
destruction of the ozone layer, human toxicity, freshwater ecotoxicity, terrestrial toxicity, acidification and eutrophication.

The environmental impacts associated to life cycle of beef tallow biodiesel are superior to life cycle of soybean biodiesel in only two impact categories: land use and global warming.

When the results are analyzed considering its significance in all the weighted results, the most relevant environmental impacts in the life cycle of the products analyzed (normalization) are obtained. The Figure 4 presents a comparison of environmental impact by category for life cycle of soybean biodiesel and for life cycle of beef tallow biodiesel by normalization criterion. The results show that the categories of land use impact and global warming are responsible for the greater environmental impacts in both life cycles analyzed.

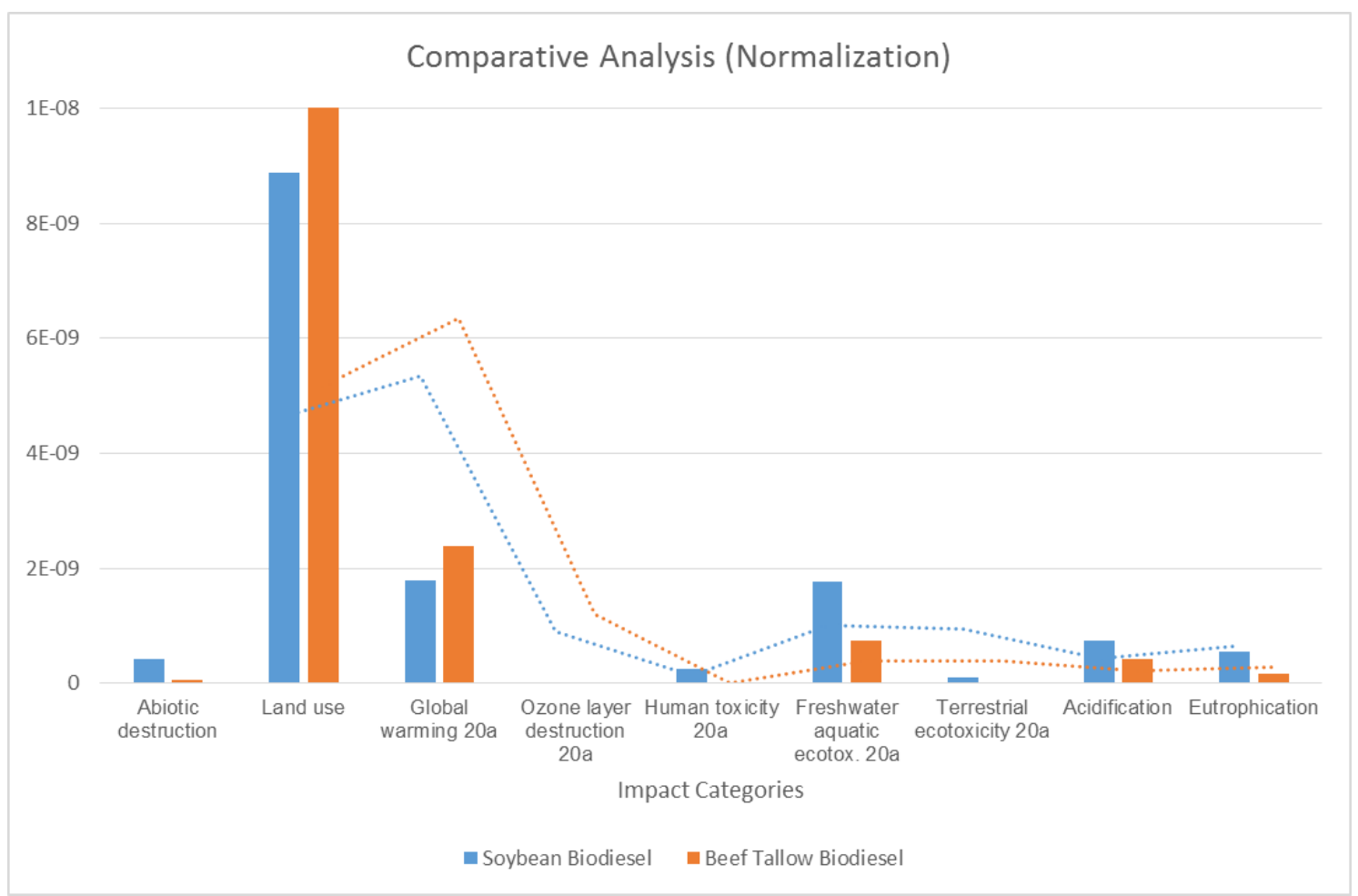

Figure 4. Comparative analysis of the impacts (normalization)

\section{DISCUSSION}

Clearly, the agricultural stage requires large occupation and transformation of green area for both process of the soybean crop as for cattle pasture. The results show that land use is more striking in the case of the biodiesel production process obtained from beef tallow than it is for the production of soybean biodiesel process. 
INDEPENDENT JOURNAL OF MANAGEMENT \& PRODUCTION (IJM\&P)

http://www.ijmp.jor.br

v. 8, n. 4, October - December 2017

ISSN: 2236-269X

DOI: 10.14807/ijmp.v8i4.644

In normalized values, environmental impacts related to land use in the production process of biodiesel from beef tallow is more relevant about $15 \%$ than the same impacts in the production process of biodiesel from soybeans. This result occurs due to the necessary area for such activities, a pasture area larger than the soybean planting being required in order to reach $1 \mathrm{GJ}$ of energy provided by the use of biodiesel obtained by raw materials. Several studies are related with the environmental impacts of agricultural activities in Brazil and worldwide. Domingues and Bermann (2012), based on numerous surveys conducted in the work, attribute the environmental impacts related to land use in the cattle industry more incisors than in soybean farming.

The production of beef tallow biodiesel uses of a co-product of meat. There are not cattle ranching aimed to producing biofuel. It is unthinkable this possibility. However these results serve to further discussions about the environmental impacts arising from livestock activities. The intensive land use by livestock production causes irreversible environmental impacts, such as compaction and soil sealing by the force exerted by the animals, erosion, contamination by pesticides, impacts at the expense of removal of native vegetation of continuous and extensive areas, silting of rivers and reservoirs, loss of biodiversity, loss of natural areas and eutrophication (MOURI; ASAKI, 2015).

Based on the biology of ruminant herbivores it is possible to understand that methane production is part of the digestive process occurring in those animals prestomach (rumen). The fermentation of plant material ingested into the rumen is an anaerobic process which converts cellulosic carbohydrates to short chain fatty acids. In making up this transformation, it releases heat, which is dissipated as heat by metabolic body surface, which are produced carbon dioxide $\left(\mathrm{CO}_{2}\right)$ and methane $\left(\mathrm{CH}_{4}\right)$. According to data from Brazilian Agricultural Research Agency - EMBRAPA (2002), the intensity of methane emissions depends on the type of animal, the amount and degree of mass intake and digestibility effort to undergoing the animal. In another study of EMBRAPA (2003), it is shown that the average age of cattle slaughtering is three years and the average methane generation per head is $47 \mathrm{~kg} /$ year. With these data it is concluded that an ox generates, over its useful period, approximately $140 \mathrm{~kg}$ of methane. Based on this information it can understand the results shown in Figure 4, which point more relevant environmental 
INDEPENDENT JOURNAL OF MANAGEMENT \& PRODUCTION (IJM\&P)

http://www.ijmp.jor.br

v. 8, n. 4, October - December 2017

ISSN: 2236-269X

DOI: 10.14807/ijmp.v8i4.644

impacts to the issues of climate change to the production process of biodiesel from beef tallow.

As livestock requires large green areas for grazing, and with that, there are several studies showing the close link between cattle ranching and deforestation of native forests, the occupation and transformation of these areas contribute quite significantly to increase these results.

What can explain the slight advantage of the process from soybean over the beef tallow is the capturing of the $\mathrm{CO}_{2}$ emitted at ground transformation process by the very culture of soybeans in the soybean cultivation stage. Another aspect that contributed to the consolidation of the results due to climatic changes in the case involving soybean is the use of road transport between the stages of the production chain, especially in transport after the agricultural stage, whose average distance the extraction step of soybean oil was considered as $90 \mathrm{~km}$. Therefore, the advantage of soybean biodiesel production process of the process of production of beef tallow biodiesel could be even larger if it were adopted other transportation modes to transport the grains and soybean oil, such as rail, due to its higher load capacity.

The results point to greater impacts related to the destruction of abiotic resources in the production of soybean biodiesel. The major contributions to this impact category are in the extraction, production and application of phosphate fertilizers, since, due to the biological nitrogen fixation by the plant, no nitrogen fertilization is required for soybean cultivation. Extraction of phosphate rock requires the use of off-road vehicles with high fossil fuel consumption. Once extracted, the ore is processed in units with high fuel and energy needs, which greatly increases the contribution of the impact on the demand of phosphate fertilizers required for cattle production, for the production of bovine tallow biodiesel.

It is well known that human activities have released gases into the atmosphere that have depleted the ozone layer. Emissions to the atmosphere are mainly from chlorofluorocarbon gases, the so-called CFCs, whose use has been extremely exploited until about a decade ago. Its use has now been discouraged in the industry by the academy and environmental organizations that have lobbied governments around the world. However, it is not difficult, even today, to find the widespread use of these gases in refrigeration compressors, in the polymer 
INDEPENDENT JOURNAL OF MANAGEMENT \& PRODUCTION (IJM\&P)

http://www.ijmp.jor.br

v. 8, n. 4, October - December 2017

ISSN: 2236-269X

DOI: 10.14807/ijmp.v8i4.644

expansion industry, in the production of aerosol products and other ozone-depleting substances, such as pesticides, methyl chloroform and substances used in fire extinguishers.

In the production process of biodiesel from beef tallow the greatest contribution to the destruction of the ozone layer comes from the production of steam used in the refrigeration processes. In the cold process, the use of steam and heated water favors the cutting of the meat and the separation of the parts of the slaughtered animal, besides promoting compliance with the hygiene requirements established by sanitary surveillance. However, water vapor is touted as a major contributor to the greenhouse effect. Since the publication of the fourth report of the IPCC in 2007, water vapor is considered one of the main mechanisms causing global warming as it acts as an amplifier of temperature rise.

Human toxicity is caused by anthropogenic activities that emit highly poisonous chemicals that reach humans through the environment. This is due to the characteristics of the substances in combination with the mode of emission. The routes of poisoning are by breathing (via atmosphere) or by ingested materials (WENZEL et al.,1997).

The results of this LCA study show that bovine tallow biodiesel takes advantage of soybean biodiesel to the impact category referring to human toxicity with the most significant contributions by the use of the compounds chlorophenols and other pesticides in pest control in soybean cultivation.

The problem of freshwater and terrestrial ecotoxicity occurs similarly to processes that affect human toxicity. The major contribution to the ecotoxicity of fresh water to the soybean biodiesel production process comes from the production of glyphosate, an aminophosphonate analogous to the natural amino acid glycine, which is used as the main ingredient of various herbicides.

One factor that contributes greatly to this result is the need to use fossil fuel burning in the application processes of fertilizers and pesticides along the whole extension of the soybean crop. In addition to considering, however, the emissions from the production processes of these same fertilizers and pesticides, whose contributions were taken into account in the life cycle inventory, through the Ecoinvent v3 data library. 
INDEPENDENT JOURNAL OF MANAGEMENT \& PRODUCTION (IJM\&P)

http://www.ijmp.jor.br

v. 8, n. 4, October - December 2017

ISSN: 2236-269X

DOI: 10.14807/ijmp.v8i4.644

In the case of the production of bovine tallow biodiesel, in addition to the burning of fossil fuel, may have helped to raise the percentage of contributions to acidification emissions from the electricity consumption of the national electricity system, much consumed in slaughter and refrigerator. Inputs and outputs related to the production, distribution and consumption of electricity were made possible by the use of the Ecoinvent v3 data library.

Eutrophication is strongly affected by $\mathrm{NO}_{x}$ emissions, which has as main contributor the use of electric energy in the models that give the inventory of the life cycle of the Brazilian energy matrix and is widely used throughout the biodiesel production process both for soybean and for bovine tallow.

\section{CONCLUSIONS}

The overall results show that the production of soybean biodiesel process provides greater environmental impact for seven of the nine impact categories analyzed: abiotic depletion resources, ozone layer depletion, human toxicity, freshwater ecotoxicity, terrestrial ecotoxicity, acidification and eutrophication. However, in the two categories that the production process of beef tallow biodiesel provides biggest environmental impacts, when compared to soybean biodiesel production process (land use and climate change - global warming), the damages have more significant impacts in the study. Thus, they are impacts that cause much more severe and significant damage to the whole assembly in analysis.

Regarding the steps that most impact the environment, it is clear that agricultural steps for both processes are those that contribute most to environmental degradation. However, it is necessary to clarify that the production of beef tallow biodiesel exists only because there is the meat production process. Currently, there's no exist a marketing opportunity to produce cattle aimed at supplying the biofuel market. What does not happen the same in the case of soybean. It has been seen entire harvests of soybeans being sold for the production of biodiesel and not to supply the food market.

\section{ACKNOWLEDGEMENTS}

The authors are grateful to the National Research Council of Brazil (CNPq) and to the Coordination for Higher Education Staff Development (CAPES) for the financial support. 
DOI: 10.14807/ijmp.v8i4.644

\section{REFERENCES}

ABNT - BRAZILIAN ASSOCIATION OF TECHNICAL STANDARDS. (2009). NBR ISO 14040: Environmental management - Life cycle assessment - Principles and Framework (in Portuguese). Brazil.

BEEFPOINT. (2013). Consumption of animal by-products is growing worldwide, and adding value is the challenge (in Portuguese). Available: http://www.beefpoint.com.br/cadeia-produtiva/aproveitamento-de-subprodutosanimais-esta-em-crescimento-no-mundo-e-agregar-valor-e-o-desafio. Access 09th September, 15.

BOCCARDO, R. C. (2004). Current overview of biodiesel. Monograph, Brazilian Training Program in Engines and Fuels (in Portuguese), Curitiba, Brazil.

CÁRDENAS, O. (2011). Heat transfer study in flame tube furnace using tallow as fuel (in Portuguese). Ph.D. Thesis (Mechanical Engineering). Escola de Engenharia de São Carlos, Universidade de São Paulo, São Carlos, p. 1-89.

CAVALETT, O. (2008). Analysis of Soy life cycle (in Portuguese). Ph.D. Thesis (Food Engineering). Faculdade de Engenharia de Alimentos, Universidade Estadual de Campinas, Campinas, p. 1-245.

CEDERBERG, C.; FLYSJÖ, A. (2004). Environmental Assessment of future pig farming systems. Report from the Swedish institute for food and biotechnology.

CHUA, C. B. H.; LEE, H. M.; CHOONG, J. S. (2010). Low, Life cycle emissions and energy study of biodiesel derived from waste cooking oil and diesel in Singapore, International Journal of Life Cycle Assess,n. 15, p. 417-423.

COSTA NETO, P. R.; ROSSI, L. F. S.; ZAGONEL, G. F.; RAMOS, L. P. (2000). Alternative Biofuel production to diesel oil through transesterification of soybean oil used for frying (in Portuguese). Química Nova, v. 23, n. 4, p. 531-537.

CUNHA, J. T. (2008). Inventory life cycle of beef tallow and soybean biodiesel and diesel oil for use in city buses in São Paulo, SP. M.Sc. dissertation (Environmental Technology: Environmental Management). Instituto de Pesquisas Tecnológicas do Estado de São Paulo, IPTEC, São Paulo, p. 1-141.

DEMIRBAS, A. (2009). Biofuels securing the planet's future energy needs. Energy Conversion and Management, v. 50, n. 9, p. 2239-2249.

DOMINGUES, M. S.; BERMANN, C. (2012). O arco do desmatamento na Amazônia: da pecuária à soja. Ambiente \& Sociedade, v. XV, n. 2, São Paulo, 22p.

DUFOUR, J.; IRIBARREN, D. (2012). Life cycle assessment of biodiesel production from free fatty acid-rich wastes, Renewable Energy n. 38, p. 155-162.

EMBRAPA - Brazilian Agricultural Research Corporation. (2003). Beef cattle breeding in the southeastern region: market and marketing. Brasília, 79p. Available:

http://sistemasdeproducao.cnptia.embrapa.br/FontesHTML/BovinoCorte/BovinoCort eRegiaoSudeste/mercados.htm. Access: 09th September, 2015.

EMBRAPA - Brazilian Agricultural Research Corporation. (2002). First Brazilian inventory of anthropogenic emissions of greenhouse gases: methane emissions in livestock. Brasília: IBGE, p. 1-79. 
ESTEVES, R. A.; PEREIRA, R. G. (2016). Análise sobre a evolução do biodiesel no Brasil. Revista Espacios (Caracas), v. 37, n. 2, p. 5-23.

FELÍCIO, P. E. (1998). The farmer receives for the meat, but the ox is not only made of steaks (in Portuguese). C.R.M.V. São Paulo, v. 26, p. 15-17.

HANSEN, S. B.; OLSEN. S. I.; UJANG, Z. (2014). Carbon balance impacts of land use changes related to the life cycle of Malaysian palm oil-derived biodiesel, International Journal of Life Cycle Assess, n. 19, p. 558-566.

ISO 14040 (2009) Environmental management - Life cycle assessment Requirements and guidelines. International Organization for Standardization, Switzerland.

JANULIS, P. (2004). Reduction of energy consumption in biodiesel fuel life cycle. Renewable Energy, v. 29, n. 6, p. 861-871.

LOPES, E. M. (2006). Energy analysis and technical feasibility of producing biodiesel from tallow. M.Sc. dissertation (Energy Engineering). Universidade Federal de Itajubá, Itajubá, MG, p. 1-120.

MANIK, Y.; LEAHY, J.; HALOG, A. (2013). Social life cycle assessment of palm oil biodiesel: a case study in Jambi Province of Indonesia, International Journal of Life Cycle Assess, n. 18, p.1386-1392.

MME, Ministry of Mines and Energy. (2003). Final report of the inter-ministerial working group in charge of presenting studies on the feasibility of using vegetable oil - biodiesel as an alternative energy source (in Portuguese), Brasília, Brazil, p. 1-15.

MORAIS, S.; MATA, T. M.; MARTINS, A. A.; PINTO, G. A., COSTA, C. A. V. (2010). Simulation and life cycle assessment of process design alternatives for biodiesel production from waste vegetables oils. Journal of Cleaner Production, v. 18, p. 1251-1259.

MOURI, G.; AISAKI, N. (2015). Using land-use management policies to reduce the environmental impacts of livestock farming. Ecological Complexity, n. 22, p.169177.

NAE - Center of Strategic Affairs of the Presidency of the Republic. (2005). NAE notebooks: Biofuels (in Portuguese), Secretary of Government Communication and Strategic Management. Caderno $\mathrm{n}^{\circ}$. 02. Brasília, Brazil.

PEREIRA, R. G.; OLIVEIRA, C. D.; OLIVEIRA, J. L.; OLIVEIRA, P. C. P.; FELLOWS, C. E.; PIAMBA, O. E. (2007). Exhaust emissions and electric energy generation in a stationary engine using blends of diesel and soybean biodiesel. Renewable Energy, v. 32, n. 14, p. 2453-2460.

QUEIRÓS, J.; MALCA, J.; FREIRE, F. (2015). Environmental life-cycle assessment of rapeseed produced in Central Europe: addressing alternative fertilization and management practices, Journal of Cleaner Production, n. 99, p. 266-274.

ROCHA, T. B. (2011). Harmonization of biofuels life cycle inventories in Brazil, M.Sc. thesis (Master in Engineering) - Programa de Pós-graduação em Engenharia Mecânica e de Materiais, Universidade Tecnológica Federal do Paraná, Curitiba, p. 1-104. 
SANDER, K.; MURTHY, G. S. (2010). Life cycle analysis of algae biodiesel, International Journal of Life Cycle Assess, n. 15, p. 704-714.

SPINELLI, D.; JEZ, S.; POGNI, R.; BAOSOSI, R. (2013). Environmental and life cycle analysis of a biodiesel production line from sunflower in the Province of Siena (Italy), Energy Policy, n. 59, p. 492-506.

VIANA, M. M. (2008). Inventory sunflower oil Biodiesel life cycle. M.Sc. dissertation (Chemical Engineering). Escola Politécnica, Universidade de São Paulo, São Paulo, p. 1-230.

WENZEL. H.; HAUSCHILD, M.; ALTING L. (1997) Environmental assessment of products. Bonton/Dordrecht/London: Kluwer Academic Publisehrs. v.1 e 2.

WILLERS, C. D. (2014). Environmental Impact Assessment of semi-intensive beef cattle. M.Sc. dissertation (Environmental Sciences). Escola de Meio Ambiente e Desenvolvimento, Universidade Estadual do Sudoeste da Bahia, Itapetinga, p. 186. 